\title{
PENGARUH TAX AVOIDANCE, PENERAPAN SANKSI PAJAK DAN PELAYANAN PERPAJAKAN TERHADAP KEPATUHAN WAJIB PAJAK (Studi Empiris Pada Wajib Pajak Orang Pribadi di KPP Pratama Jakarta Setiabudi Dua)
}

\author{
${ }^{1}$ Ferry Halimi, ${ }^{2}$ Waluyo \\ ${ }^{1}$ Magister Akuntansi, Fakultas Ekonomi Universitas Tarumanagara \\ Email:ferrhal@yahoo.com \\ ${ }^{2}$ Dosen Fakultas Ekonomi, Universitas Tarumanagara \\ Email:waluyo@mercubuana.ic.id
}

Masuk : 08-10-2019, revisi: 27-10-2019, diterima untuk diterbitkan : 30-10-2019

\begin{abstract}
ABSTRAK
Tujuan penelitian ini yaitu untuk menganalisis pengaruh tax avoidance, penerapan sanksi pajak dan pelayanan perpajakan terhadap kepatuhan wajib pajak orang pribadi di KPP Pratama Jakarta Setiabudi Dua. Penelitian ini mengambil sampel sebanyak 90 responden dengan teknik purposive sampling. Data dikumpulkan dengan instrumen kuesioner yang diukur dengan skala Likert. Analisis data yang digunakan yaitu partial least square (PLS) dengan bantuan program SmartPLS versi 3.0. Hasil analisis data membuktikan bahwa: (1) Tax avoidance berpengaruh negatif dan signifikan terhadap kepatuhan wajib pajak orang pribadi dengan nilai koefisien $\left(b_{1}\right)=-0.343$ dan signifikansi $<0,05$, (2) Penerapan sanksi pajak berpengaruh positif dan signifikan terhadap kepatuhan wajib pajak orang pribadi dengan nilai koefisien $\left(b_{2}\right)=0.242$ dan signifikansi $<0,05$, dan (3) Pelayanan perpajakan berpengaruh positif dan signifikan terhadap kepatuhan wajib pajak orang pribadi dengan nilai koefisien $\left(b_{3}\right)=0.283$ dan signifikansi $<0,05$.
\end{abstract}

Kata Kunci: Tax Avoidance, Sanksi Pajak, Pelayanan Perpajakan, Kepatuhan Wajib Pajak.

\section{ABSTRACT}

The purpose of this study is to analyze the effect of tax avoidance, the application of tax sanctions and tax services on individual taxpayer compliance at KPP Pratama Jakarta Setiabudi Dua. This study took a sample of 90 respondents with purposive sampling technique. Data was collected by questionnaire instruments measured by a Likert scale. Data analysis used is partial least square $(P L S)$ with the help of the SmartPLS version 3.0 program. The results of data analysis prove that: (1) Tax avoidance has a negative and significant effect on individual taxpayer compliance with a coefficient $(b 1)=-0.343$ and significance $<0.05$, (2) Application of tax sanctions has a positive and significant effect on mandatory compliance personal tax with a coefficient $($ b2) $=0.242$ and significance $<0.05$, and (3) Tax service has a positive and significant effect on individual taxpayer compliance with a coefficient $(b 3)=0.283$ and significance $<0.05$.

Keywords: Tax Avoidance, Tax Sanctions, Tax Services, Taxpayer Compliance.

\section{PENDAHULUAN}

Penerimaan pajak menjadi pilar utama penerimaan negara dalam Anggaran Penerimaan dan Belanja Negara (APBN). Undang-Undang APBN mengamanatkan agar prioritas sasaran pembangunan nasional dan prioritas nasional lainnya dapat tercapai, salah satu hal yang perlu dilakukan pemerintah adalah mengoptimalkan penerimaan perpajakan. Pemerintah menargetkan penerimaan perpajakan yang meningkat dari tahun ke tahun. Dalam kurun waktu 5 tahun terakhir ini, penetapan kenaikan target penerimaan pajak selalu diatas 20\%. Puncaknya pada tahun 2015 ketika target pajak naik hingga mencapai 30\%, ditengah kondisi tidak tercapainya target pajak pada tahun sebelumnya. 
Pada tahun 2017, Menteri Keuangan mengambil kebijakan tegas, dengan tidak menaikkan target pajak sebagiamana tahun-tahun sebelumnya. Asumsinya bahwa postur APBN harus kredibel dan itu dimulai dengan penetapan target yang mendekati kondisi yang sebenarnya. Setelah basis pajak dibenahi tahun 2017, tahun-tahun berikutnya pajak akan bergerak lebih agresif dan terukur (Saeroji, 2017).

Penerimaan pajak akan meningkat dengan seiring meningkatnya kepatuhan wajib pajak dalam melaporkan hartanya. Kepatuhan wajib pajak merupakan perilaku seorang wajib pajak dimana dalam menjalani semua kewajiban perpajakan dan menggunakan hak perpajakannya wajib pajak tetap berpatokan pada perundang-undangan yang berlaku (Susmita dan Supatmi, 2016). Tingkat kepatuhan wajib pajak di Indonesia masih kecil dalam periode 2015 dan 2016 yaitu 0,66\%. Rasio kepatuhan wajib pajak periode 2016 hanya 60,82\%. Tingkat kepatuhan wajib pajak ini masih didominasi pada kepatuhan wajib pajak orang pribadi, bukan wajib pajak pengusaha. Semakin tinggi tingkat kepatuhan pajak, baik secara formal atau material, maka akan memperbesar basis pemajakan. Ini berakibat akan semakin besar penerimaan pajak yang dapat dihimpun.

Salah satu kota yang memberikan kontribusi pajak terbesar yaitu DKI Jakarta yang mana nominal estimasi yang diharapkan pada tahun 2016 yaitu RP 226.816.690 juta, namun hanya terealisasi sebesar Rp 204.773.778 juta (Direktorat Jenderal Pajak, 2016). Tingkat realisasi yang jauh dari yang di estimasikan ini dimungkinkan karena kurangnya kepatuhan Wajib Pajak dalam melaporkan semua harta yang dimiliki secara tepat waktu.

Ada berbagai karakteristik wajib pajak dalam meminimalisir pengeluaran untuk pajak mereka, diantaranya tax avoidance. Melakukan tax avoidance masih dapat diperbolehkan jika tetap dalam koridor ketentuan perpajakan. Perlu adanya sanksi perpajakan sebagai alat pencegahan agar angka tax avoidance yang dilakukan Wajib Pajak dapat ditekan, sehingga penerimaan negara dapat meningkat. Maryati dan Supriyanto (2015), meyatakan bahwa tax avoidance berpengaruh negatif dengan kepatuhan pajak. Penerapan sanksi juga memiliki peranan penting dalam meningkatkan kepatuha pajak. Penelitian yang dilakukan oleh Santika (2015), menyatakan bahwa sanksi pajak berpengaruh signifikan terhadap kepatuhan wajib pajak. Begitu juga pelayanan perpajakan, pelayanan yang sesuai dengan kebutuhan wajib pajak akan memberi banyak kemudahan tentunya dan membuat wajib pajak merasa puas dalam proses pelaporan pajaknya yang pada ahirnya tingkat kepatuhan pajaknya semakin meningkat. Nurhakim dan Pratomo (2015) membuktikan bahwa kualitas pelayanan berpengaruh positif terhadap kepatuhan wajib pajak.

Melalui permasalahan yang telah diuraikan maka penelitian ini memiliki tujuan diantaranya:

1. Untuk menguji secara empiris pengaruh tax avoidance terhadap kepatuhan wajib pajak orang pribadi di KPP Pratama Jakarta Setiabudi Dua.

2. Untuk menguji secara empiris pengaruh penerapan sanksi pajak terhadap kepatuhan wajib pajak orang pribadi di KPP Pratama Jakarta Setiabudi Dua.

3. Untuk menguji secara empiris pengaruh pelayanan perpajakan terhadap kepatuhan wajib pajak orang pribadi di KPP Pratama Jakarta Setiabudi Dua.

\section{LANDASAN TEORI}

\section{Tax Avoidance}

Tax avoidance atau perlawanan terhadap pajak adalah hambatan- hambatan yang terjadi dalam pemungutan pajak, sehingga mengakibatkan berkurangnya penerimaan kas negara. Tax Avoidance selalu diartikan sebagai kegiatan yang legal (Bambang, 2009). Tax avoidance adalah 
cara untuk menghindari pembayaran pajak secara legal yang dilakukan oleh Wajib Pajak dengan cara mengurangi jumlah pajak terutangnya tanpa melanggar peraturan perpajakan atau dengan istilah lainnya mencari kelemahan peraturan (Hutagaol, 2007). Selanjutnya Zain (2005) mendefenisikan tax avoidance adalah proses pengendalian tindakan agar terhindar dari konsekwensi pengenaan pajak yang tidak dikehendaki.

Adapun yang menjadi penyebab dalam tax avoidance menurut Ancok (2004), adalah sebagai berikut:

1. Kurangnya Pengetahuan tentang Pajak

Secara teoritik, menumbuhkan sikap positif terhadap sesuatu harus bermula dari adanya pengetahuan tentang hal tersebut. Bagaimana kegiatan peningkatan pengetahuan tentang pajak dilakukan dibeberapa negara dikemukakan oleh Lewis (1982).

2. Sikap Petugas Pajak

Petugas pajak diharapkan simpatik, bersifat membantu, mudah dihubungi, dan bekerja jujur. Bila petugas berbuat yang tidak sesuai dengan ketentuan, maka status mereka sama dengan pagar yang memakan tanaman. Tanpa ada perubahan ke arah perilaku yang simpatik dan kejujuran dalam bertugas di kalangan para petugas pajak, maka sulit untuk menumbuhkan kesadaran masyarakat untuk membayar pajak.

3. Sistem Pajak dan Pelaksanaan Pajak

Kemudahan dalam memperoleh, mengisi, dan mengembalikan SPT, akan menentukan kegairahan untuk membayar pajak. Selain itu, keadilan dalam jumlah pajak yang harus dibayar, baik "keadilan horisontal" maupun "keadilan vertikal" sangat menentukan keikhlasan dan antusiasme membayar pajak

\section{Penerapan Sanksi Pajak}

Sanksi perpajakan merupakan jaminan bahwa ketentuan peraturan perundang-undangan perpajakan (norma perpajakan) akan dituruti/ditaati/ dipatuhi, dengan kata lain sanksi perpajakan merupakan alat pencegah agar wajib pajak tidak melanggar norma perpajakan (Mardiasmo, 2011). Menurut Nugroho (2006) menyatakan bahwa: "Sanksi adalah hukuman negatif kepada orang yang melanggar peraturan" Menurut Zain (2008) persepsi atas sanksi perpajakan adalah: "Interpretasi dan pandangan wajib pajak dengan adanya sanksi perpajakan." Wajib pajak akan memenuhi kewajiban perpajakannya bila memandang bahwa sanksi perpajakan akan lebih banyak merugikannya (Nugroho, 2006).

Menurut Indonesian Tax Review yang dikutip oleh Hakim (2015), menyebutkan bahwa dalam undang-undang perpajakan dikenal dua macam sanksi, yaitu:

1. Sanksi Administrasi

Sanksi administrasi merupakan pembayaran kerugian kepada Negara khususnya berupa bunga, dan kenaikan. Sanksi administrasi dapat dijatuhkan apabila Wajib Pajak melakukan pelanggaran, terutama atas kewajiban yang ditentukan dalam UU KUP. Sanksi administrasi ini dibagi menjadi:

a. Sanksi Administrasi berupa Denda

Sanksi denda adalah jenis sanksi yang paling banyak ditemukan dalam Undang-Undang perpajakan. Terkait besarnya denda dapat ditetapkan sebesar jumlah tertentu, presentase dari jumlah tertentu atau suatu angka perkalian dari jumlah tertentu. Pada sejumlah pelanggaran, sanksi denda ini akan ditambah dengan sanksi pidana. Pelanggaran yang juga dikenai sanksi pidana yakni pelanggaran yang sifatnya disengaja. 
b. Sanksi Administrasi berupa Bunga

Sanksi administrasi berupa bunga dikenakan atas pelanggaran yang menyebabkan utang pajak menjadi lebih besar. Jumlah bunga dihitung berdasarkan presentase tertentu dari suatu jumlah, mulai dari saat bunga itu menjadi hak atau kewajiban sampai dengan saat diterima atau dibayarkan.

c. Sanksi Administrasi berupa Kenaikan

Jika melihat dari bentuknya, bisa jadi sanksi administrasi berupa kenaikan merupakan sanksi yang paling ditakuti oleh Wajib Pajak. Hal ini karena bila dikenakan sanksi tersebut, jumlah pajak yang harus dibayar bisa menjadi berlipat ganda. Sanksi berupa kenaikan pada dasarnya dihitung dengan angka presentase tertentu dari jumlah pajak yang harus dibayar.

2. Sanksi Pidana

Sanksi pidana merupakan suatu alat terakhir atau benteng hukum yang digunakan oleh fiskus agar norma perpajakan dipatuhi, yang terdiri dari:

a. Kurungan Pidana kurungan hanya diancamkan kepada tindak pidana yang bersifat pelanggaran, dapat ditujukan kepada Wajib Pajak dan pihak ketiga.

b. Penjara Pidana penjara seperti halnya pidana kurungan, merupakan hukuman perampasan kemerdekaan. Pidana penjara diancamkan terhadap kejahatan.

\section{Pelayanan Perpajakan}

Pelayanan pada kantor perpajakan dapat diartikan sebagai pelayanan yang diberikan oleh Direktorat Jenderal Pajak kepada wajib pajak untuk membantu wajib pajak memenuhi kewajiban perpajakannya (Mangonting, 2013). Pelayanan yang berkulitas menurut Supadmi (2009) adalah pelayanan yang dapat memberikan kepuasan kepada wajib pajak dan tetap dalam batas memenuhi standar pelayanan yang dapat dipertanggungjawabkan serta harus dilakukan secara terus-menerus.

Parasuraman et al dalam Sunyoto (2014) menyebutkan lima dimensi pokok dari kualitas pelayanan (service quality) yaitu:

1. Bukti langsung (tangibles)

Pada hakekatnya bukti lansung berkaitan dengan kemampuan suatu perusahaan dalam menunjukkan eksistensinya kepada pihak eksternal. Penampilan dan kemampuan sarana dan prasarana fisik perusahaan yang dapat diandalkan serta keadaan lingkungan sekitarnya merupakan salah satu cara perusahaan jasa dalam menyajikan kualitas layanan terhadap pelanggan. Diantaranya meliputi fasilitas fisik (gedung, buku, rak buku, meja dan kursi, dan sebagainya), teknologi (peralatan dan perlengkapan yang dipergunakan), serta penampilan pegawai.

2. Keandalan (reliability)

Keandalan merupakan kemampuan perusahaan memberikan pelayanan sesuai dengan apa yang dijanjikan secara akurat dan terpercaya. Kinerja harus sesuai dengan harapan pelanggan yang tercermin dari ketepatan waktu, pelayanan yang sama untuk semua pelanggan tanpa kesalahan, sikap simpatik dan akurasi yang tinggi.

3. Daya tanggap (responsiveness)

Daya tanggap merupakan kemauan untuk membantu pelanggan dan memberikan jasa dengan cepat dan tepat dengan penyampaian informasi yang jelas. Mengabaikan dan membiarkan pelanggan menunggu tanpa alasan yang jelas menyebabkan persepsi yang negative dalam kualitas pelayanan. 


\section{Jaminan (assurance)}

Jaminan/assurance dalam hal ini mencangkup pengetahuan, kesopan-santunan dan kemampuan para pegawai perusahaan untuk menumbuhkan rasa percaya para pelanggan kepada perusahaan.

5. Empati (empathy)

Empati berkaitan dengan pemberikan perhatian yang tulus dan bersifat individual atau pribadi yang diberikan kepada pelanggan dengan berupaya memahami keinginan konsumen dimana suatu perusahaan diharapkan memiliki suatu pengertian dan pengetahuan tentang pelanggan, memahami kebutuhan pelanggan secara spesifik, serta memiliki waktu pengoperasian yang nyaman bagi pelanggan.

\section{Kepatuhan Pajak}

Kepatuhan wajib pajak dapat diartikan sebagai perilaku seorang wajib pajak dimana dalam menjalani semua kewajiban perpajakan dan menggunakan hak perpajakannya wajib pajak tetap berpatokan pada perundang-undangan yang berlaku (Susmita dan Supatmi, 2016). Kepatuhan pajak dapat didefinisikan sebagai tingkat dimana wajib pajak mematuhi atau tidak mematuhi peraturan pajak negara mereka (Marziana et al,. 2010).

Kepatuhan wajib pajak berdasarkan Keputusan Menteri Keuangan Nomor 235/KMK.03/2003 tanggal 3 Juni 2003, Wajib pajak dapat ditetapkan sebagai WP patuh yang dapat diberikan pengembalian pendahuluan kelebihan pembayaran pajak apabila memenuhi semua syarat sebagai berikut:

1. Tepat waktu dalam menyampaikan SPT Tahunan dalam 2 (dua) tahun terakhir;

2. Dalam tahun terakhir penyampaian SPT Masa yang terlambat tidak lebih dari 3 (tiga) masa pajak untuk setiap jenis pajak berikutnya;

a. SPT Masa yang terlambat itu disampaikan tidak lewat dari batas waktu penyampaian SPT Masa pajak berikutnya;

- Tidak mempunyai tunggakan pajak untuk semua jenis pajak

- Kecuali telah memperoleh izin untuk mengansur atau menunda pembayaran pajak;

- Tidak termasuk tunggakan pajak sehubungan dengan STP yang diterbitkan untuk 2 (dua) masa pajak terakhir.

b. Tidak pernah dijatuhi hukuman karena melakukan tindak pidana di bidang perpajakan dalam jangka waktu 10 (sepuluh) tahun; dan

c. Dalam hal laporan keuangan diaudit oleh akuntan publik atau Badan Pengawasan Keuangan dan Pembangunan harus dengan pendapat wajar dengan pengecualian sepanjang pengecualian tersebut tidak mempengaruhi laba rugi fiskal.

\section{Tax Avoidance dan Variabel Kepatuhan Wajib Pajak}

Kewajiban perpajakan tetap harus dilakukan berdasarkan undang-undang dan aturan yang berlaku. Tax avoidance yang dilakukan oleh Wajib Pajak memang tindakan yang legal, selama tidak menyalahi aturan perundang-undangan perpajakan, tetapi jika dilihat dari segi penerimaan negara pastinya akan berkurang karena Wajib Pajak mencari celah untuk mengatur pajaknya tanpa harus melanggar aturan perpajakan.

Perilaku tax avoidance mengindikasikan bahwa wajib pajak tersebut memiliki tingkat kepatuhan yang rendah. Hal ini didukung oleh penelitian Maryati dan Supriyanto (2015) yang meyatakan bahwa variabel tax avoidance (tax avoidance) berpengaruh negatif dengan kepatuhan pajak. 


\section{Penerapan Sanksi Pajak dan Kepatuhan Wajib Pajak}

Penerapan sanksi pajak juga memberikan kontribusi dalam meningkatkan rasio kepatuhan wajib pajak. Penerapan sanksi pajak memiliki peranan penting dalam meningkatkan kepatuhan wajib pajak dalam melaporkan pajak secara tepat waktu. Hal ini didukung oleh Penelitian yang dilakukan oleh Ngadiman dan Huslin (2015) membuktikan bahwa sanksi pajak berpengaruh positif dan signifikan terhadap kepatuhan wajib pajak. Kemudan Ariesta dan Latifak (2017) juga menegaskan bahwa sanksi pajak berpengaruh terhadap tingkat kepatuhan wajib pajak. Temuan tersebut juga didukung oleh penelitian Pranata Setiawan (2015) dan Tiraada (2013).

\section{Pelayanan Perpajakan dan Kepatuhan Wajib Pajak}

Pelayanan perpajakan juga penting dalam kaitannya peningkatan kepatuhan wajib pajak. Pelayanan sendiri pada sektor perpajakan dapat diartikan sebagai pelayanan yang diberikan kepada Wajib Pajak oleh Direktorat Jenderal Pajak untuk membantu Wajib Pajak memenuhi kewajiban perpajakannya. Pelayanan yang sesuai dengan kebutuhan wajib pajak dan yang memberi banyak kenudahan tentunya akan membuat wajib pajak merasa puas dalah proses pelaporan pajak pada ahirnya tingkat kepatuhannya semakin meningkat. Dengan kata lain, semakin baik kualitas dari pelayanan perpajakan yang diberikan memungkinkan dapat meningkatkan rasio kepatuhan wajib pajak.

Hal ini didukung oleh penelitian yang dilakukan oleh Nurhakim dan Pratomo (2015) juga membuktikan bahwa kualitas pelayanan berpengaruh positif terhadap kepatuhan wajib pajak. Temuan tersebut juga dikuatkan oleh hasil penelitian Dewi dan Supadmi (2014) yang menyatakan bahwa kualitas pelayanan berpengaruh positif pada tingkat kepatuhan Wajib Pajak.

Penelitian ini dilakukan pada wajib pajak orang pribadi yang terdaftar di KPP Pratama Jakarta Setiabudi Dua. Dengan demikian dapat digambarkan model konseptual:

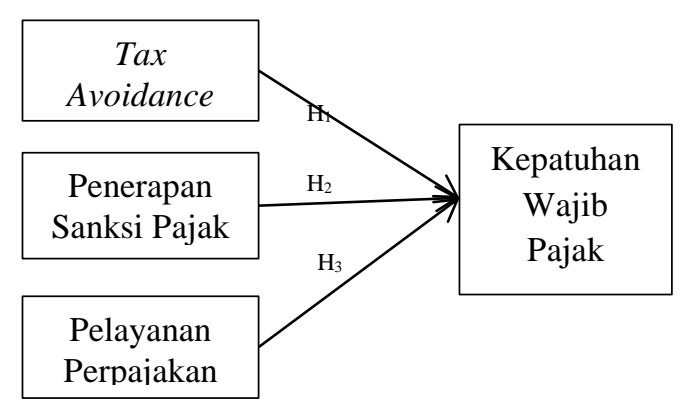

Gambar 2.1Kerangka Konseptual

$\mathrm{H}_{1}$ : Tax avoidance berpengaruh negatif terhadap kepatuhan wajib pajak.

$\mathrm{H} 2$ : Penerapan sanksi pajak berpengaruh positif terhadap kepatuhan wajib pajak.

H3 : Pelayanan perpajakan berpengaruh positif terhadap kepatuhan wajib pajak

\section{METODE PENELITIAN}

Penelitian ini dikategorikan sebagai penelitian kuantitatif dengan desain kausalitas. desain kausal berguna untuk mengukur hubungan-hubungan antar variabel penelitian atau berguna untuk menganalisis bagaimana suatu variabel mempengaruhi variabel lain (Umar, 2011). Data yang digunakan merupakan data primer yang diperoleh melalui kuesioner yang diukur melalui skala likert. Populasi dalam penelitian ini adalah semua wajib pajak orang pribadi terdaftar di KPP Pratama Jakarta Setiabudi Dua. Sampel penelitian berjumlah 90 wajib pajak yang diambil 
melalui metode purposive sampling yaitu teknik pengambilan sampel berdasarkan kriteria yang ditetapkan peneliti. Adapun kriteria yang ditetapkan adalah sebagai berikut.

1. Merupakan wajib pajak orang pribadi yang terdaftar di KPP Pratama Jakarta Setiabudi Dua.

2. Berada di lokasi saat penelitian dilakukan.

Pengujian hipotesis melalui analisis data statistic Partial Least Square (PLS) untuk memperkirakan model jalur yang menggunakan variabel atau konstruk laten dengan berbagai indikator.

\section{ANALISIS}

Responden yang menjadi subjek dalam penelitian ini yaitu wajib pajak orang pribadi yang terdaftar di KPP Pratama Jakarta Setiabudi Dua dan memiliki kegiatan usaha. Data responden dapat disajikan dalam chart berikut.

Gambar
Deskripsi
Responden
Analisis data
digunakan
partial least
yang mana
ini dilakukan
menguji
yang berkaitan
pengaruh tax
avoidance,
penerapan
pajak dan
pelayanan
perpajakan
parsial

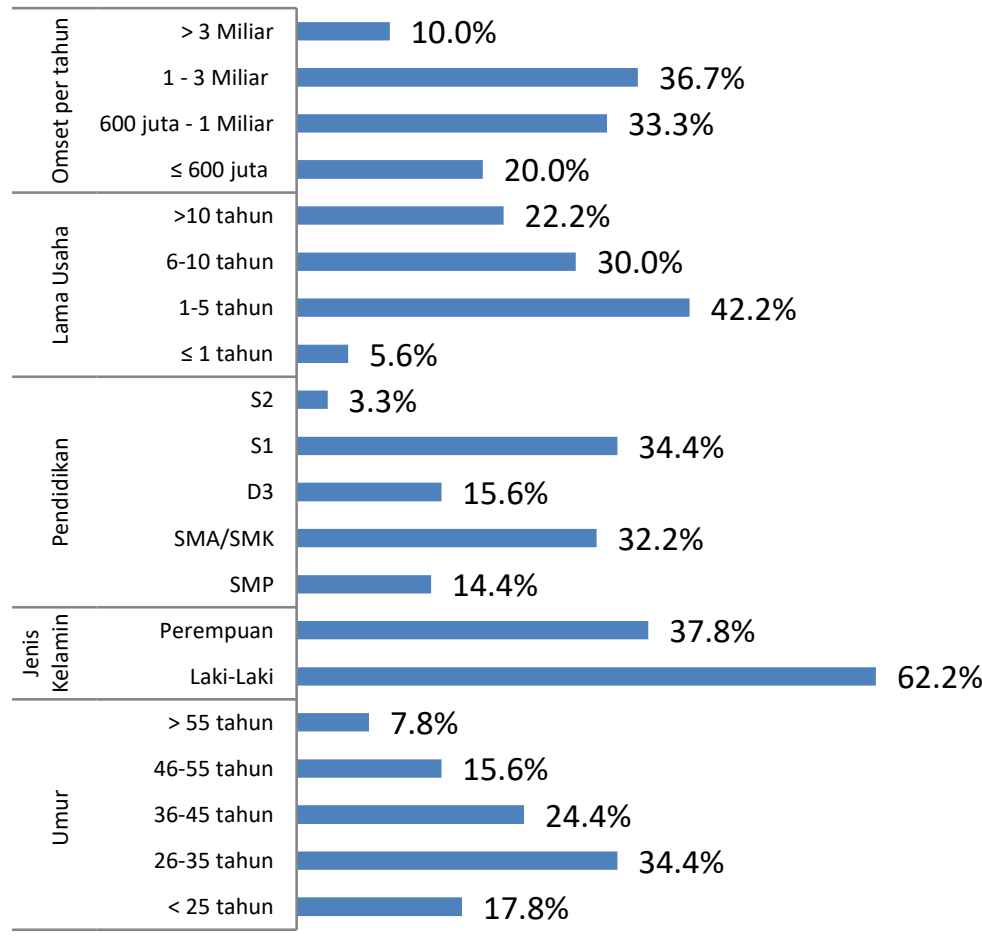

1.

kepatuhan

pajak. Dalam analisis PLS terbagi dalam dua pengujian yaitu evaluasi outer model dan evaluasi inner model seperti yang diuraikan sebagai berikut.

\section{Evaluasi Outer Model}

Analisa outer model dilakukan untuk memastikan bahwa measurement model yang digunakan layak untuk dijadikan pengukuran dengan memenuhi asumsi validitas dan reliabilitas.

\section{Uji Validitas}

Dalam pengujian dengan PLS, validitas instrumen terbagi menjadi dua yaitu validitas konvergen (convergent validity) dan validitas diskriminan (discriminant validity). Uji validitas konvergen dapat dilihat dari besarnya nilai loading factor sedangkan uji validitas diskriminan dapat dilihat dari nilai cross loading antara indikator dengan konstruknya maupun nilai Average Variance Extracted (AVE).

a. Uji Validitas Konvergen

Uji validitas konvergen dapat dilihat dari nilai loading factor seperti pada tabel berikut. 
Tabel 1 Validitas Konvergen Sumber: Data diolah dengan SmartPLS (2018)

\begin{tabular}{lcc}
\hline Variabel & No Item & Loading Factor \\
\hline Kepatuhan & Kwp1 & 0.804 \\
Wajib & Kwp2 & 0.821 \\
Pajak & Kwp3 & 0.866 \\
& Kwp4 & 0.836 \\
\hline Tax & Pp1 & 0.731 \\
Avoidance & Pp2 & 0.817 \\
& Pp3 & 0.816 \\
& Pp4 & 0.866 \\
\hline Penerapan & Psp1 & 0.824 \\
Sanksi & Psp2 & 0.787 \\
Pajak & Psp3 & 0.815 \\
& Psp4 & 0.867 \\
& Psp5 & 0.776 \\
\hline Pelayanan & P1 & 0.749 \\
Perpajakan & P2 & 0.855 \\
& P3 & 0.830 \\
& P4 & 0.754 \\
& P5 & 0.742 \\
\hline
\end{tabular}

Uji validitas konvergen dapat dilihat dari besarnya nilai loading factor pada setiap butir indikator. Hasil analisis menunjukkan bahwa semua indikator pada variabel kepatuhan wajib pajak, tax avoidance, penerapan sanksi pajak dan pelayanan perpajakan memiliki nilai loading factor $>0,7$. Hal ini menunjukkan bahwa semua indikator dalam penelitian ini telah memenuhi asumsi validitas konvergen.

b. Uji Validitas Diskriminan

Uji validitas diskriminan dapat dilihat dari nilai Average Variance Extrated (AVE), yang mana indikator yang valid harus memenuhi syarat yaitu AVE $>0,5$. Nilai AVE selengkapnya dapat dilihat pada tabel berikut.

Tabel 2 Validitas Diskriminan

Sumber: Data diolah dengan SmartPLS (2018)

\begin{tabular}{ll}
\hline Variabel & AVE \\
\hline Kepatuhan Wajib Pajak & 0.663 \\
Pelayanan Perpajakan & 0.692 \\
Penerapan Sanksi Pajak & 0.620 \\
Tax Avoidance & 0.655 \\
\hline
\end{tabular}

\section{Uji Reliabilitas}

Uji Reliabilitas dilakukan dengan menggunakan indikator Cronbach's Alpha seperti yang disajikan dalam tabel berikut. 
Tabel 3 Uji Reliabilitas

Sumber: Data diolah dengan SmartPLS (2018)

\begin{tabular}{lc}
\hline \multicolumn{1}{c}{ Variabel } & $\begin{array}{c}\text { Cronbach } \\
\text { Alpha }\end{array}$ \\
\hline Kepatuhan Wajib Pajak & 0.852 \\
Pelayanan Perpajakan & 0.846 \\
Penerapan Sanksi Pajak & 0.873 \\
Tax Avoidance & 0.825 \\
\hline
\end{tabular}

Hasil uji reliabilitas menunjukan bahwa semua variabel telah memiliki nilai Cronbachs Alpha $\geq$ 0,7. Hal ini menunjukkan bahwa semua kuesioner telah reliabel.

\section{Evaluasi Inner Model}

Pada evaluasi iner model dilakukan dengan melihat besarnya nilai $\mathrm{R}$ Square, yang mana nilai $R$ Square yang dihasilkan yaitu 0,673. Nilai ini menjelaskan bahwa variabel tax avoidance, penerapan sanksi dan pelayanan perpajakan mampu menjalskan variabel jepatuhan wajib pajak sebesar $67,3 \%$ sedangkan sisanya dijelaskan oleh variabel lain diluar mode.

Pengujian ini dilakukan dengan dasar hasil pengolahan data yang telah dilakukan dengan menggunakan program PLS. Hasil pengujian ini akan menunjukan apakah semua jalur yang dianalisis menunjukan hasil yang signifikan terlihat dari hasil koefisien (original sample) dan tstatistic nya serta nilai $\mathrm{p}$ value. Hasil estimasi $t$-statistik dapat dilihat pada path coefficient ( $t$ statistics) berikut.

Tabel 4. Path Coefficient

Sumber: Data diolah dengan SmartPLS (2018)

\begin{tabular}{lcccc}
\hline & Koefisien & $\mathrm{T}_{\text {Satatistic }}$ & $\mathrm{P}_{\text {Value }}$ & Ket. \\
\hline Tax Avoidance & -0.343 & 2.857 & 0.005 & Signifikan \\
Penerapan Sanksi Pajak & 0.242 & 1.962 & 0.048 & Signifikan \\
Pelayanan Perpajakan & 0.283 & 2.673 & 0.009 & Signifikan \\
\hline
\end{tabular}

\section{HASIL DAN PEMBAHASAN}

\section{Hipotesis 1}

Hasil analisis data dengan partial least square diperoleh nilai koefisien $\left(\mathrm{b}_{1}\right)=-0.343$ dengan $\mathrm{t}$ hitung $=2,857$ dan probabilitas signifikansi ( $p$ value) yaitu 0,005. Dengan demikian terlihat bahwa nilai koefisien $\left(b_{1}\right)<0$, artinya tax avoidance berpengaruh negatif terhadap kepatuhan wajib pajak. Adapun tingkat signifikansi dari pengaruh tersebut dapat dilihat dari nilai $t$ hitung dan $\mathrm{p}$ value, yang mana dikatakan berpengaruh signifikan ketika nilai $\mathrm{t}$ hitung $>1,96$ dan $p$ value $<0,05$. Dengan demikian dapat dikatakan bahwa tax avoidance berpengaruh negatif dan signifikan terhadap kepatuhan wajib pajak. Temuan ini memberikan sebuah bukti bahwa dengan meningkatnya perilaku tax avoidance, maka akan menurunkan tingkat kepatuhan pajak. Begitu pula sebaliknya, dengan menurunnya perilaku tax avoidance maka dapat meningkatkan kepatuhan pajak dalam memenuhi kewajiban pajaknya. 


\section{Hipotesis 2}

Hasil analisis data dengan partial least square diperoleh nilai koefisien $\left(\mathrm{b}_{2}\right)=0.242$ dengan $\mathrm{t}$ hitung $=1,962$ dan probabilitas signifikansi ( $p$ value) yaitu 0,048. Dengan demikian terlihat bahwa nilai koefisien $\left(b_{1}\right)>0$, artinya penerapan sanksi pajak berpengaruh positif terhadap kepatuhan wajib pajak. Adapun tingkat signifikansi dari pengaruh tersebut dapat dilihat dari nilai $\mathrm{t}$ hitung dan $\mathrm{p}$ value, yang mana dikatakan berpengaruh signifikan ketika nilai $\mathrm{t}$ hitung $>1,96$ dan $p$ value $<0,05$. Dengan demikian dapat dikatakan bahwa penerapan sanksi pajak berpengaruh positif dan signifikan terhadap kepatuhan wajib pajak. Temuan ini memberikan sebuah bukti bahwa dengan adanya penerapan sanksi pajak, maka dapat meningkatkan kepatuhan pajak. Begipula sebaliknya, dengan semakin tidak diterapkannya sanksi pajak, kepatuhan pajak menjadi menurun.

\section{Hipotesis 3}

Hasil analisis data dengan partial least square diperoleh nilai koefisien $\left(b_{2}\right)=0.283$ dengan $t$ hitung $=2,673$ dan probabilitas signifikansi ( $p$ value) yaitu 0,009. Dengan demikian terlihat bahwa nilai koefisien $\left(\mathrm{b}_{3}\right)>0$, artinya pelayanan perpajakan berpengaruh positif terhadap kepatuhan wajib pajak. Adapun tingkat signifikansi dari pengaruh tersebut dapat dilihat dari nilai $\mathrm{t}$ hitung dan $\mathrm{p}$ value, yang mana dikatakan berpengaruh signifikan ketika nilai $\mathrm{t}$ hitung $>1,96$ dan $p$ value $<0,05$. Dengan demikian dapat dikatakan bahwa pelayanan perpajakan berpengaruh positif dan signifikan terhadap kepatuhan wajib pajak. Temuan ini memberikan sebuah bukti bahwa melalui pelayanan perpajakan yang sesuai dengan harapan wajib pajak, maka dapat meningkatkan kepatuhan pajak. Begipula sebaliknya, dengan semakin kurang sesuainya pelayanan perpajakan maka dapat menurunkan kepatuhan pajak dalam memenuhi kewajiban pajaknya.

Peningkatan pelayanan perpajakan oleh Direktorat Jenderal Pajak sebagai bentuk upaya meningkatkan kepatuhan wajib pajak sudah dilakukan dan diperbaharui secara terus menerus, salah satunya adalah pelaporan pajak secara on line. Hal ini memberikan kemudahan dan efisiensi dari sisi waktu dan biaya, karena dapat dilakukan diluar jam kerja kantor dan tidak perlu mengirim berkas laporan yang dicetak ke kantor pelayanan pajak.

\section{KESIMPULAN DAN SARAN}

Dari hasil analisis data dan pembahasan yang telah diuraikan pada bagian sebelumnya, dapat disimpulkan bahwa:

1. Tax avoidance berpengaruh negatif dan signifikan terhadap kepatuhan wajib pajak orang pribadi yang terdaftar di KPP Pratama Jakarta Setiabudi Dua.

2. Penerapan sanksi pajak berpengaruh positif dan signifikan terhadap kepatuhan wajib pajak orang pribadi yang terdaftar di KPP Pratama Jakarta Setiabudi Dua.

3. Pelayanan perpajakan berpengaruh positif dan signifikan terhadap kepatuhan wajib pajak orang pribadi yang terdaftar di KPP Pratama Jakarta Setiabudi Dua.

Temuan dalam penelitian ini memberikan bukti bahwa penerapan sanksi pajak dan pelayanan perpajakan memberikan dampak positif pada kepatuhan wajib pajak. Untuk itu sebagai upaya dalam meningkatkan penerimaan pajak, maka Direktorat Jenderal Pajak diharap dapat benarbenar menerapkan sanksi pada wajib pajak yang melanggar ketentuan dalam perpajakan agar para wajib pajak dapat menerima efek jera, sehingga menjadi patuh dalam melaporkan pajak. Selain itu, petugas pajak juga diharap dapat memberikan pelayanan yang memuaskan dan memberikan kemudahan dalam pelaporan wajib pajak. 
Bagi peneliti selanjutnya diharap dapat mengembangkan penelitian ini dengan mengambil sampel yang lebih luas lagi serta melakukan perbandingan tingkat kepatuhan wajib pajak dari setiap sub wilayah tersebut, misalnya dengan mengambil semua wilayah DKI Jakarta dan melakukan komparasi antar wilayah kota di Jakarta.

\section{REFERENSI}

Ancok, Djamaludin. 2004. Psikologi Terapan (Applied Psychology). Yogyakarta: Darussalam. Bambang Darussalam. 2009. Upaya Menangkal Praktik Penghindaran Pajak. Diakses melalui: http://www.pbtaxand.com/news/2009/12/upayamenangkal-praktik-penghindaran-pajak.

Dewi, Cahaya Sinta dan Lupadmi, Nih Luh. 2014. Pengaruh Pemeriksaan Pajak, Kesadaran, Kualitas Pelayanan Pada Tingkat Kepatuhan Wajib Pajak Badan. E-Jurnal Akuntansi Universitas Udayana, vol.9, no.2, h. 505-514.

Hutagaol, John, Darussalam dan Danny Septriadi. 2007. Kapita Selekta Perpajakan. Jakarta: Penerbit Salemba Empat.

Mayanti, Eny dan Supriyono, Raden. 2015. Analisa Faktor-Faktor Yang Mempengaruhi Tax Compliance Pajak Penghasilan (Studi Empiris Terhadap Wajib Pajak Orang Pribadi Di Kanwil DJP Jakarta Pusat Dan Jawa Barat I). Jurnal Akuntansi Universitas Gunadarma.

Marziana Bt. Hj. Mohamad, Norkhazimah Bt. Ahmad and Mohmad Sakarnor Bin Deris. 2010. The Relationship Between Perceptions and Level of Compliance Under Self Assessment System-A Study in The East Coast Region. Journal of Global Business and Economics, vol.1, no.1, h. 241-257.

Mustafa, Zainal dan Wijaya, Tony. 2012. Panduan Teknik Statistik SEM dan PLS dengan SPSS Amos. Yogyakarta: Cahaya Atma Pustaka.

Nugroho, Agus. 2006. Pengaruh Sikap Wajib Pajak pada Pelaksanaan Sanksi Denda, Pelayanan Fiskus, dan Kesadaran Perpajakan Terhadap Kepatuhan Wajib Pajak Studi Empiris Terhadap Wajib Pajak Orang Pribadi di Kota Semarang. Unisversitas Diponegoro: Tesis Megister Akuntansi.

Rahayu, Siti Kurnia. 2013. Perpajakan Indonesia: Konsep \& Aspek Formal. Yogyakarta: Graha Ilmu.

Saeroji, Oji. 2017. Menakar Kadar Kepatuhan Wajib Pajak. http://www.pajak.go.id/content/article/menakar-kadar-kepatuhanwajib-pajak.

Santika, Kadek Adi. 2015. Pengaruh Kesadaran WP, Kualitas Pelayanan, Dan Sanksi Perpajakan Pada Kepatuhan WP Air Tanah. E-jurnal akuntansi universitas udayana, Vol.12, No.3, h. 656-670.

Sunyoto, Danang. 2014. Konsep Dasar Riset Pemasaran \& Perilaku Konsumen. Yogyakarta : CAPS.

Susmita, Putu Rara Dan Ni Luh Supatmi. 2016. Pengaruh kualitas pelayanan, sanksi perpajakan, biaya kepatuhan pajak, dan penerapan e-filing pada kepatuhan wajib pajak. E-journal akuntansi Universitas Udayana, vol.14, no.2, h.1239- 1269.

Umar, Husein. 2011. Metode Penelitian untuk Skripsi dan Tesis Bisnis, Edisi Kedua. Jakarta: PT. Raja Grafindo Persada.

Zain, Mohammad. 2008. Manajemen Perpajakan Edisi 3. Jakarta: Salemba Empat.

Waluyo. 2017. Tax Amnesty and Tax Administration System: An Empirical Study in Indonesia. European Research Studies Journal, vol.20, no.4B, h.548-556.

Waluyo. 2017. Perpajakan Indonesia. Jakarta: Salemba Empat.

Nzioki, Paul Muoki dan Peter, Osebe Rawlings. 2014. Analysis of Factors Affecting Tax Compliance in Real Estate Sector: A Case of Real Estate Owners in Nakuru Town, Kenya. Research Journal of Finance and Accounting, Vol.5, No.11, 2014, hal 1-14 